\title{
The Significance of Learning English in Saudi Arabia
}

Hamoud Althobaiti (Corresponding author)

Ministry of Education, Taif Education Department, Saudi Arabia

Email: d00h@hotmail.com

Received: $24 / 06 / 2020$

Accepted: 11/08/2020

Published: 01/09/2020

Volume: 1 Issue: 3

How to cite this paper: Althobaiti, H. (2020). The Significance of Learning English in Saudi Arabia. Journal of Critical Studies in Language and Literature, 1(3), 20-24

DOI: https://doi.org/10.46809/jcsll.v1i3.25

Copyright (C) 2020 by author(s) and Global Talent Academy Ltd. This work is licensed under the Creative Commons Attribution International License (CC BY 4.0).

http://creativecommons.org/licenses/by/4.0/

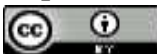

\begin{abstract}
English as an international language is the main means of communication worldwide. Many people strive to learn English language greatly, and this has contributed to the customization of international special curricula in English language. In Saudi Arabia, learning English is becoming highly important; as it has been introduced into the Saudi Secondary School classroom and curriculum from grade seven. This paper aims to outline the significance of developing English language learning for Saudi Arabia's students and government.
\end{abstract}

Keywords: EIL, Saudi Arabia, Curriculum, Inner Circle, Globalisation

\section{Introduction}

English is considered the most important language in the world. This status is due largely to the benefits, which people see in acquiring English as a second language for use at businesses, social occasions, or educational institutions. As a result, there has been a huge increase in the number of people acquiring English as a second language (McKay, 2003). Therefore, there has been an increase in the number of organizations teaching English across the world.

The social and political landscape of the Kingdom of Saudi Arabia has undergone great changes in recent years and due to this development, the need for continuing to teach English and modernize current facilities is required to maintain the global standards. This idea is supported by Al-Nofaie (2010) who further underlines the importance of learning a second language, in particular English, for the use of transferring knowledge from one community to the other because of the importance of globalisation. Along with the transferring of knowledge, people will also be able to communicate their regional cultures and traditions more efficiently to a foreign audience (Assulaimani, 2019).

English language has various forms such as British English, American English, or Australasian English (Jenkins, 2009); however, regardless of these different types, English is taught as an International Language (EIL) in the Saudi Arabia's secondary schools. This study addresses the significance of English language in the Saudi Arabia and also presents an introduction on the definition of variety of English and its relevance to the Saudi Arabia's secondary schools. Afterward, the study gives an account of what EIL is and its significance for Saudi Arabia. 


\section{Importance of English Language for Saudi Students}

This section introduces the importance of English in Saudi Arabia and presents a literature review on the student's needs for learning English and how Saudi students potentially use English as an International Language.

In Saudi Arabia, English is taught as a foreign language and as a compulsory subject from grade seven onwards. Unfortunately, there has been a culture that Saudi students choose to learn English as a "gap filler" that is a redundant subject studied for advancing onto the forthcoming year. This culture has fortunately been changing for the past few years as more students have chosen to learn English for academic and employment-related purposes (Mahibur, 2011). There has been a non-stop effort by the government of Saudi Arabia in aid with certain experts who try to provide students with a suitable curriculum depending on their level of development. Moreover, the decision makers for a long time have decided to teach British English and American English in the curriculum (Khan, 2011).

A study suggested that the education system in the Kingdom of Saudi Arabia is improving rapidly; however, this is not true for learners of English as a foreign language (Mahibur and Alhaisoni, 2013). As a result, emphases have been put on improving the education system to supply a more widespread and efficient method for teaching English as a foreign language. One movement has been to introduce compulsory English language learning from class six onwards to the university level. The Ministry of Education suggested that they may reduce it to class four with the intention of encouraging students to start learning English in an early age (Mahibur and Alhaisoni, 2013). The expectation of students who learn English as a foreign language is to participate in the sharing of knowledge with colleagues across the globe. This knowledge is expected to take all forms such as technological, scientific, cultural and financial (Liton, 2012). The importance of finding a job is also an encouraging factor for students learning English as a foreign language as language skills are moving from being desirable skills to being essential skills in obtaining employment in both public and private sectors (Mahibur, 2011).

Alqurashi (2011) conducted a survey on a number of students who learnt English as a foreign language. He found out that the majority of participants wanted to learn English for communication purposes with people all over the world. Alqurashi also reported that some students were learning English in order to travel aboard for academic, business, and tourism purposes. Mahibur and Alhaisoni (2013) supported similar ideas. They tried to outline specifically how students learn the language. They pointed out that the student must obtain basic language skills for international communication goals. The students must be encouraged to develop a positive attitude towards learning English. This would help them obtain the required linguistic proficiency in different settings such as social, academic, or business. This could also help the students tackle with cultural and social issues within their society and make them involved in inter-faith discussion with people from all over the world. Moreover, being linguistically proficient in English to enhance concepts such as international cooperation would develop the understanding between nations with cultural differences (Elyas and Al-Ghamdi, 2018).

In reference to the global community, Saudi Arabia is the center of the second-largest religion-Islam- in the world. Thus, it is important for Saudi Arabia's students to acquire English in order to communicate with foreign pilgrims who come to Saudi Arabia at religious festivals and ceremonies (Parris, Estrada, and Honigsfeld, 2018). This is important both on an economic scale and on a social scale. For the economy, as pilgrims come to Saudi Arabia, local businesses can gain the market through offering quality products to the traveling pilgrims at a fair price.

\section{What Is Variety and Why Is It Important?}

There are three concentric circles of defining the origins of English, which help in the general understanding of who can use English as an EIL. English as an International Language is not restricted to a group of local people or a single country; it has expanded throughout the globe and is used readily. This section will describe the variety of English and the three concentric circle models.

Smith (1976) stated that although there is only one English language, there are many varieties of this. For example, in America, a different form of English is used, which is often defined as 'American English'. Although the language is essentially the same, it varies in spelling and vocabulary items. An example of this is the missing letter ' $u$ ' in the spelling of 'colour' (color for American English). Some vocabulary varies, such as a 'bin' in British English and a 'trash can' in American English. There is also variation in the stress, intonation, and grammar in either version of English. Although there may be some difficulties in understanding the language variations between different English (American and British) the language will be understood and communication can still take place. Furthermore, Smith (1976) defined two different types of English and the importance they have on different English speakers. The first is first language English that is defined as a language that a country uses as its primary means of communication (e.g. Britain, America, and Australia). The second is auxiliary English; English that is spoken but not widely used to communicate. Countries such as Japan have auxiliary English as they frequently use English in their lexicon. Words such as 'supermarket' are spoken in English as there is no Japanese equivalent, but English is not used to communicate with one another.

Kachru (1992) described the "three concentric circles" model of English and identified the models through the types of spread; the patterns of acquisition, and the functional allocation of English in diverse cultural contexts. The three concentric circles consist of an Inner Circle, Outer Circle, and an Expanded Circle. The Inner Circle consists of countries where English is the native language and are the traditional cultural and linguistic bases of English, countries such as the UK, USA, and Canada. The Outer Circle consists of countries where English is institutionalized via prior colonization by Inner Circle 
countries, countries such as Ghana, India, and Singapore. The third model, the Expanding Circle, consists of countries wherein English is spoken as a foreign language and the level of English is not well defined, countries such as China, Zimbabwe, and Saudi Arabia.

Kachru argued that varieties of English have developed over the last few decades even though colonialism spread English in the 1700s and English was widely used as a language of power. English has become a lingua franca and was widely used in commerce, trade, and studied for its heritage.

English has changed and developed over the last few decades due to colonization and the influence of other languages and cultures. Thus, this is important to consider these changes and variations in teaching English. Furthermore, considering these varieties lets English continue to be used as an international language with the potential for further variations (Kachru, 1992).

\section{English as an International Language}

This segment introduces the idea of what English as an International Language (EIL) is. EIL is misunderstood as certain people believe it is a new form of the English Language; however, this is not the case. Seidlhofer (2003), in her report commissioned by the Council of Europe, defined English as International Language that is used by native and bilingual English speakers to enable the mixing of cultures via communication.

English has become a language that is used globally and is demanded to be taught to second language speakers. However, Jenkins (2000) argued that there are variations in the way English is taught as an EIL, some more beneficial and more widely recognized than others. Jenkins stated that English as an international language can be divided into two categories; the 'teachability' and 'learnability'- the way English is taught can fluctuate with who is teaching and who is learning. The variations between who is teaching English could result in what is being taught. For example, a native speaker of English may teach in a different way from a fluent second language speaker; they may have different methods of teaching but the result of their teaching could be different. The accent of the teacher may affect the pronunciation of the learner, resulting in a variation of the original English. In addition, the outcomes of the language may have different expectations.

Jenkins also argues that teaching English is still too prosaic and structured around what is perceived to be the correct way of teaching English. This is something that native speakers of English do more often than second language teachers do. The author attributes this to the prejudices and stereotypes still held against people with regional accents such as Glasgow and Birmingham, resulting in a standard RP (Received Pronunciation) English being taught. Often regional dialects are associated with the working classes and often looked down upon. Furthermore, Jenkins believed that many native English speakers still teach English as an international language using the RP pronunciations, but argues this may be an out of date teaching style as only the 'inner circle' of the language users consider this acceptable and many other English speakers such as countries in the 'outer circle' only need to use English as a mean of communication and do not hold judgments based on accent and dialect. It is more important to teach intelligibility in English as an international language as well as an appropriate understanding of regional dialect and culture than it is to teach RP (Received Pronunciation) or GA (General American). In fact, it is the teachability of English that is important rather than the correct way of pronouncing a word. A student must understand the language, enjoy it, understand the cultural relevance, and be able to use it how they need to.

\section{Teaching English in Saudi Arabian Secondary Schools}

This segment discusses why English should be the EIL to be taught in Saudi secondary schools. There has been an increase in bilingualism in Saudi Arabia is due to both internal and external factors. The domestic economy is the driving force for internal reasons along with industrialization and Saudi nationalization, and the global economy along with sociopolitical and economic developments being the external reason. In this case, EIL could be the ideal method of communication between all people. Bieswanger (2008) supported the idea that EIL is the ideal method of international communication and therefore suggested that English is the most important language to the global community as it is used in many sectors such as economy and tourism as well as science and technology.

At the same level of importance, but this time at the local level, English is the main language used not only in world trade but also in domestic trade. As previously mentioned, pilgrims are coming to Saudi Arabia for the religious pilgrimage from over 150 different countries. In times of the pilgrimage, Saudi Arabia truly becomes a global economy within a domestic society in the context of communication. During the pilgrimage, there is trade inside the country; however, this trade occurs between local Saudi Arabians and the representatives of the 150 different countries who bring different English language varieties with them. This is a good chance for Saudi Arabians to work with these pilgrims with English Language varieties. Alqurashi (2011) supported the idea that Saudi Arabians must continue to develop their English Language skills with the help and encouragement of the government.

Even though Saudi Arabia's economy is largely supported by oil-related products, it is still very much affected by global economic changes. A trade boost can incur when there is an increased number of people acquiring EIL skills in Saudi Arabia as this gives local Saudi Arabians a platform for communicating with not only incoming religious pilgrims but with incoming skilled professionals. What is described here is a truly inter cross-border trade business where incoming pilgrims, who are trading within Saudi Arabia, are not only purchasing goods from locals but are exchanging goods. This, therefore, removes 
the complex cross-border international trade system where more than one country is involved in selling or manufacturing a product (Sekhar, 2012).

\section{Implication}

The discussion can be concluded by mentioning that whether it is for trading, travelling, education, or any other goals, the most suitable English language variety for unifying and allowing a platform for communication between people from different countries who speak different languages is EIL. Therefore, EIL should be introduced to teachers and students on a systematic basis to ease them into a new system. Mahibur and Alhaisoni (2013) support this method as they mention the importance of a teacher-training program in successfully implementing an improved method for teaching English as a foreign language in Saudi Arabia.

The availability of the number of online sources of authentic audio samples for EIL has also increased. This, therefore, can enable an expansion of useful classroom materials to expand students' knowledge. The use of the Internet as a teaching resource in Saudi Arabia could be an extremely successful source, according to Baik \& Shim (2002).

\section{Conclusion}

The most popular language in the world is English. Because of this popularity, there has been a huge increase in the number of English language learners worldwide. The same can be said of Saudi Arabia where there has been massive investment in trying to encourage local Saudi Arabians to learn English as a foreign language. There are many forms of English as mentioned in this paper such as British English, American English; however, the best type of English to be taught in Saudi Arabia is EIL and that is due to its widespread connectivity throughout the globe.

For local Saudi Arabians, to learn and use EIL would benefit them immensely as this would boost local trade businesses and form new international partnership with incoming tourists and pilgrims. Another reason for the importance to learn and use EIL is for cultural and historical exchanges.

EIL is not a dialect of English or a new form of the English language but rather a standardization of the generally Inner Sphere models which is taught on a massive scale in order to provide a level platform for all who are trying to acquire English as a foreign language.

\section{References}

Al-Nofaie, H. (2010). The Attitudes of Teachers and Students towards Using Arabic in EFL Classrooms in Saudi Public Schools - A Case Study. Novitas-ROYAL Research on Youth and Language, 4 (1): 64-95.

Alqurashi, F. (2011). Teaching English for Police Purposes in Saudi Arabia: An Exploratory Study. Journal of Language Teaching and Research, 2 (4): 845- 849.

Assulaimani, T. (2019). The Future of Teaching English in Saudi Arabia. Universal Journal of Educational Research, 7, 3549.

Baik, M. J., \& Shim, R. J. (2002). Teaching World Englishes via the Internet. World Englishes, 21(3), 427-430.

Bieswanger, M. (2008). Varieties of English in Ccurrent English Language Teaching. Stellenbosch Papers in Linguistics 38, 27-47.

Elyas, T., \& Al-Ghamdi, A. (2018). A Critical Positivist Analysis of Tatweer Policy in Saudi Arabia, in Alexander W. Wiseman, Petrina M. Davidson (ed.) Cross-nationally Comparative, Evidence-based Educational Policymaking, and Reform. International Perspectives on Education and Society, 35, 241-276.

Jenkins, J. (2009). English as a Lingua Franca: Interpretations and Attitudes. World Englishes 28(2): 200-207.

Jenkins, J. (2000). The Phonology of English as an International Language. 1st Edition, Oxford University Press: USA.

Kachru, B. B. (1992). The Other Tongue: English across Cultures, 2nd Edition. University of Illinois Press.

Khan, I. A. (2011). The Teacher of English: Pedagogic Relevance in Saudi Arabia. English Language Teaching 4 (2): $112-$ 120.

Liton, H. A. (2012). Developing EFL Teaching and Learning Practices in Saudi Colleges: A Review. International Journal of Instruction 5 (2): 129-152.

Mahibur, R. M. (2011). English Language Teaching (ELT) in Saudi Arabia: A Study of Learners' Needs Analysis with Special Reference to Community College. (Master's Thesis). Najran University.

Mahibur, R. M., \& E. Alhaisoni (2013). Teaching English in Saudi Arabia: Prospects and Challenges. Academic Research International 4 (1): 112-118.

McKay, S.L. (2003). Toward Appropriate EIL Pedagogy: Re-examining Common ELT Assumptions. International Journal of Applied Linguistics 13 (1), 1-22.

Parris, H., Estrada, L., \& Honigsfeld, A. M. (2018). ELL Frontiers: Using Technology to Enhance Instruction for English Learners. Thousand Oaks, CA: Corwin, 33, 59.

Seidlhofer, B (2003). A Concept of International English and Related Issues: from Real English to Realistic English. Language Policy Division DG IV - Directorate of School, Out-of-School, and Higher Education. Strasbourg. 
Sekhar, R. (2012). The Impact of English Language on Contemporary world: A Global Perspective. TRANS Asian Research Journals 1 (4), 146- 155.

Smith. L. E. (1976). English as an International Auxiliary Language. RELC Journal 7(2), 38. 